\title{
Complexity and coordination in London's Silvertown Quays: how real estate developers (re)centred themselves in the planning process
}

\begin{abstract}
This paper contributes to existing research on the relational work of real estate developers to demonstrate how internal corporate complexities create opaqueness in governance settings and limit potential community engagement. This work is particularly pertinent at a time when there is renewed interest in the private sector, yet very little analysis which begins from the perspective of the developer. Drawing on the example of London's Silvertown, this paper shows how the strategies of development organisations evident in existing research, including their work with the public sector, communities and experts, require multiple levels of internal co-ordination. I argue that because of these sub-centres of power developers are able to maintain a more deeply entrenched centrality in urban governance.
\end{abstract}




\section{Introduction}

For more than three decades, developers have attempted to regenerate Silvertown Quays - part of London's Royal Docks. After many years of little progress, the 2012 London Olympics brought new energy to the project. In 2013, a development agreement was made between the landowners, the Mayor of London, and The Silvertown Partnership (TSP). After extensive deliberation, in 2016 TSP was granted planning permission by the London Borough of Newham, the local planning authority, to redevelop Silvertown Quays. This paper analyses the planning permission application to demonstrate how often hidden corporate strategies shape developers' role in urban governance. This paper therefore builds on existing analysis of the relational work of developers and their capacity to navigate and organise the institutional settings in which they function (Fainstein, 2001; Weinstein, 2014; Weber, 2015). I argue that this relational work is not the result of a single figure or central power, but rather is the product of and helps create sub-centres of control within the private sector. In turn, I argue these obfuscate responsibility during planning processes and minimise community capacity to shape urban governance. This paper therefore helps inform debates on the role of the private sector in urban governance because as Adams et al. note, unless the private sector is properly understood "the effectiveness of planning policy may be undermined, especially where the private sector is responsible for undertaking most development" (2012: 2577). Importantly, as has been well noted in existing literature, there are a multiplicity of types of developers (Coiacetto, 2007). TSP is a private developer with a very particular corporate structure, a three-way partnership, as such it is by no means representative of developers across London or beyond. Instead it is used here to present an example of how some developers, especially "established players" (Developer 1, March 2017), shape urban governance.

The paper is structured as follows: section two addresses existing literature on developers. Specifically it argues that existing research, in highlighting the breadth of relationships developers build over the course of a project, raises questions about developers' capacity to navigate their extensive network and the consequences of their strategic response. Section three introduces my methods. Section four introduces Silvertown Quays and TSP. Section five argues TSP navigate their network by creating sub-centres of power, internal to the private sector. Section six argues that as a direct consequence developers are able to more deeply entrench themselves at the centre of the urban governance. 


\section{How developers navigate real estate processes}

The burgeoning literature on real estate developers has brought the role of 'new city builders' to the forefront of urban governance analysis (Fainstein, 2001). This work has responded to critiques made in the 2000s about the lacuna of research on developers' behaviour (Coiacetto, 2001) and the importance of this for planning systems (Adams et al., 2012; Campbell et al., 2013). In doing so this work animates "the actual actors and institutions" (Weber 2015: 30 ) of urban development to reveal different types of developers (Cioacetto, 2007; Rosen 2017; Topolov, 1979), the multiplicity of functions they occupy within development processes, and the web of relationships they build over the course of project development (Halbert and Rouanet, 2014; Hyde, 2018; Robin, 2018; Weber, 2015). Crucially, in terms of developing a greater appreciation of the modus operandi of developers, this work has considered the importance of developers' relationships and underlying power dynamics (Adams et al., 2012: 2584), to reveal how a core strategy for developers is the production of relationships with the public sector, local communities, and the body of experts they rely on (Brill and Robin, 2018).

\subsection{Building relationships with the public sector}

Globally, critical urban research has argued developers exert agency and leverage closeknit relationships with the public sector to maximise their financial returns. In a North American context, the relationship between developers and the state was historically interrogated through Logan and Molotch's (1987) growth coalition thesis and later by urban regime theory (see Elkin, 1987; Stone, 1989). Regime theory, hybridising political economy and political science pluralist approaches (Mossberger and Stoker, 2001) shows how the distribution of power means that only through collaborative efforts can the financial or economic capital of the private sector can be unified with the political capital of the local state. Regimes advancing particular policy agendas therefore occur in moments where individuals or institutions identify shared believes (Stone 1989). In the UK, whilst the case of the relative inapplicability of the growth coalition thesis has been made (see Cox, 2017), regime theory has been applied to analysis of regeneration schemes. For example, Holman (2007) shows how Portsmouth's regeneration was contingent on a 'shared sense of purpose' across the public and private sector. This encourages research on schemes such as Silvertown to consider how policy agendas are stabilised, and the role of strategic relationships that straddle the publicprivate sector divide, in achieving it. 
Both growth coalition and regime theories highlight the important point that the state has always been involved in urban development, particularly housing provision (Aalbers, 2015; Rolnik, 2013), but its relationship with developers evolves over time and varies hugely by institutional setting. For example, Leffers' (2017) work in Toronto reveals how developers are able to shape legal norms. This, he argues, partially relies on a consensus during interviews that developers would 'win in court', even if the law was not on their side. Meanwhile, in various Asian cities Shatkin's $(2008$; 2011) research demonstrates the privatisation of planning, a situation which relies on close relationships between the state and market actors. He shows how in Manila, large scale developers' visions for cities are prioritised by the local authorities in what he terms 'bypass-implant urbanism' (2008: 384). For Shatkin, the ability to redefine how the city is planned in a way that reflect the imperatives of capital accumulation is, at least partly, the product of how developers have "built relationships with government actors" (2008: 387).

Shatkin (2014) also shows this deepening of connections between developers and the public sector in India. He argues that the shift from modernist planning agendas towards economic growth and capital accumulation has underpinned a changing urban politics that centers developers. In response to Mumbai's complex institutional structure, one developer assumed a "distinctive role as the project's chief architect and advocate" (Weinstein, 2014: 16). He was able to negotiate an often fragmented political situation by embedding "himself within the state's planning bureaucracies" (ibid.). However, despite first appearing to form a strategic partnership across the public-private sector divide, the developer was unable to overcome institutional and administrative weaknesses on his own. In this way research has shown how developers' agency is partly facilitated by what Roy (2009) argues is rule by informality in an Indian context. Additionally, this research highlights the importance of different scales of government, echoed by research elsewhere on the importance of the national state in shaping urban development outcomes, including developers' strategies (Gotham, 2009; Wijburg, 2019).

The capacity of developers to overcome institutional fragmentation through deliberate engagement across political scales also resonates with work that highlights developers' broader abilities to reinvent planning policy. The planning system in London has been accused of granting developers a 'tabula rasa', enabling them to dictate the terms of development trajectories (Duman et al., 2018). Following the 2012 London Olympics, models of 
governance favoured 'the activities of an elite group of private developers' (Moore et al., 2018: 27). Explicit in this analysis is the strength of developers, and their capacity to not just leverage the advantages of existing institutions, but to shape new policies in a way which benefits developers. This work is contingent on developers' relationship-building with state actors often resulting in a 'revolving door' between the public and private sector (Robin, 2018). Moreover, Robin (2018) shows how the creation of an exceptional or extra-ordinary approach to the governance of King's Cross, a development elsewhere in London, was heavily dictated by intense engagement between (part of) the planning authority and the main developer (see also Imrie, 2009). This Robin shows, was aided by the movement of actors between developers and local authorities, extending the extent to which developers are making relationships that straddle the public-private sector divide (Weinstein, 2014).

\subsection{Building relationships with communities}

Research on developers' interactions with communities is a second, though related, body of literature. This literature has revealed the extent to which developers navigate the political and planning uncertainty of local opposition through active engagement with communities (Geva and Rosen, 2018; Robin, 2018). In this respect, developers can define what constitutes the relevant community in the context of their development, and in so doing exclude actors they would prefer to avoid engaging with. Hyde (2018) analyses the seemingly benevolent actions of developers in Toronto and Vancouver to show how they are 'giving back to get ahead'. Relational work with, or for, the community became an explicit strategy where developers incorporate - and often alter in doing so - community agendas into their strategies (Domaradzka, 2019). This work draws on literature that questions whether participatory approaches in urban governance can overcome the limitations of top-down planning (Allmendinger and Haughton, 2012; Brownill and Carpenter, 2009; Healey, 1998; Sagoe, 2018).

Following a similar argument, Geva and Rosen's (2018) analysis of developers' strategies in Tel Aviv is particularly enlightening. They show how developers pro-actively shape community engagement to eliminate the threat it poses, through what they term the 'Regeneration Deal' during large-scale regeneration efforts. Developers seek consensus from communities for their projects by hiring experts to broker deals with local residents, and protest themselves from the potential risk of not being able to acquire property (for the ultimate purpose of knocking it down and rebuilding). This leads onto the next set of relationships developers curate: relationships with experts. 


\subsection{Developers' reliance and work with other private sector actors}

Developers' relationship-building with the state and local communities has resulted in them assuming a reputation of being "a proactive agent who makes things happen" (Charney, 2007: 1179). But their autonomy is contingent on an ability to mobilise political, cultural and increasingly financial resources (David and Halbert, 2014), and even 'spatial capital' (Mosselson, this issue). They articulate and enact agency through the hiring of experts (Akers, 2015; Crosby and Henneberry, 2016; Robin, 2018), whose capacities and roles vary by institutional setting (De Magalhaes, 2001). For example, developers' work with experts, such as broker and commercial consultants, enables them to navigate the financial risks of London, Johannesburg, Bangalore and Mexico City; to 'translate' the market and perceived risks, for investors (Brill and Robin, 2018; Corpatuax et al., 2009; David, 2012; Halbert and Rouanet, 2014). In this way developers are central actors in transcalar territorial networks of goervnance (Halbert and Rouanet, 2014).

Work on transcalar territorial networks has drawn particular attention to how developers anchor the agendas of 'far flung' boardrooms in urban development (Ballard and Harrison, this issue). In particular, we see the importance of understanding the variegated developers interactions with investors (van Loon, 2016). This dimension of urban development, whilst I do not operationalise the concept of financialisation here, recent debates on it (see Halbert and Attuyer, 2016; Aalbers, 2017) have afforded greater attention to developers' strategies. In particular, showing how developers translate qualitative data into financial data to show specific returns (Bitterer and Heeg 2012; Halbert and Sanfelici, 2016; Theurillat and Crevoisier, 2013), shape calculative logics (David and Halbert, 2014) and help international actors filter away the noise or problems associated with highly localised development (Searle, 2014; Rouanet and Halbert, 2016). At the same time, developers are required to engage with occupier needs and address these in project design (Fainstein, 2001; Guironnet et al., 2016; Theurillat and Crevoisier, 2014). This pressure to deliver returns, especially as urban developments are assetised and made more liquid (Gotham, 2009; Fernandez et al. 2016; Fields, 2018; Weber, 2010; Ward and Swyngedouw, 2018), results in developers acquiring new skills. As Theurillat and Crevoisier show in a Swiss context, financialisation and the associated role of developers results in them having to develop the capacity to co-ordinate "various specialized development, construction and even management professionals" (Theurillat and Crevoisier 2013: 2058). 
This role of mediator, which often places developers between the state and investors (Hofman and Aalbers, 2019; Theurillat and Crevoisier, 2013), encourages us to turn to Weber's highly influential analysis of Chicago $(2002 ; 2015)$. Weber has shown how developers in the early 2000s were heavily impacted by relationships with the financial sector. In 'From Boom to Bubble: How Finance Built Chicago' (2015) she argues developers took out loans to build generic office building in Chicago's CBD, irrespective of demand and population needs. Tracing their motivations, Weber argues developers were incentivised to over-build during this period because of demand from financial institutions for loans which they could securitise for financial gain. In this respect Weber, through an actor-orientated analysis, demonstrates the extent to which developers are heavily intertwined with other sectors, and how professional relationships which straddle industries impact developer strategies and have socio-material consequences for a city.

This interdependence of different private sector actors within one city reveals the informality of the market and the club-like nature of real estate (Attuyer et al., 2012; Brill, 2018; Weber, 2010). The recent proliferation of research on developers has, in this respect, repeatedly returned to earlier narratives on the importance of localisation (Wood, 2004; Ballard and Harrison, this issue). In doing so it demonstrates how development is characterised by informal connections and trust, where a developer's ability to source the necessary information for making decisions is dependent on the extent to which they are integrated in local networks (Weinstein, 2014). The local nature of the development industry is also evident in Henneberry and Parris' "ecology of real estate' which highlights how actors depend on 'networked reputation' (2013: 234). Social relations within the industry form latent networks which are transformed during development, and through these coalitions developers are able "to filter 'noise' - gossip, informal information and misinformation, trade stories and personal opinions - into market signals" (2013: 233). Informal exchanges therefore translate into strategic learnings for developers, but this requires them to actively engage with these networks (Brill, 2018).

The extensive relational work developers do over the course of any real estate project therefore requires them to be constantly building relationships. This work is deliberate and timeconsuming. As Fainstein explains: "one developer compared his production to a movie production, wherein he was the impresario who brought together the cast of architects, contractors, lawyers, accountants, financial consultants, investors, construction workers" (2001: 
67). Responding to idea of the developer as a conductor or coordinator, this paper seeks to understand how developers respond to the networks they build over the course a project (and any risks these might pose)? It asks: how do developers' responses further entrench or challenge their centrality in urban governance?

\section{Research Methodology}

This paper uses 30 in-depth interviews with people who work in London's real estate sector, especially in Silvertown, conducted between June 2015 and June 2017. Interviews were primarily with private sector actors and the Greater London Authority (GLA), and lasted between 40 minutes and 2 hours. Interviewees were selected following documentary and discourse analysis of media reports, policies and Silvertown's submitted masterplan, which were used to trace triangulate those who were involved during the planning application process. This desk-based research, combined with analysis of commercial reports from each of the key firms working on the site, also informed biographical analysis of each of the key actors. This focused on mapping actors' overlapping personal and professional histories, and was used to inform interviews. Following the biographical analysis and mapping of different firms' and individuals' involvement, selected interviewees were checked with two sources: the lead consultant and the GLA's lead.

Within the private sector, in an attempt to address the multiplicity of roles within real estate development processes, the following were interviewed: directors of the main development company, the lead consultants from each of the main consultancies working for the developers, architects and private sector planners. Since the focus of this analysis is the planning application stage of development, there was a deliberate attempt to cover the specialists associated with planning rules and regulation (eg heritage, community liaison). The interviews focused on (1) the strategies of the different actors, (2) what sources of information they used, (3) how they came to be involved in the project, (4) how they related to the rest of the development team and (5) their interactions with the planning authority. The interviews focused on the planning application stage of the development as the application was being made during the fieldwork period.

From the public sector, interviews were conducted with core members of relevant GLA teams, including members of the regeneration team and the land and property department. In addition, interviews were conducted with local politicians and with key members of the 
community. For the community and public sector, interviews focused on how (1) developers and other private sector actors were perceived; (2) type and means of interactions; (3) perceptions about developer strength; and (4) alternative visions for the area. Learning from Rouanet and Halbert (2016), the actors are considered in terms of economic and political power, as well as their ability to articulate a cohesive vision for the site. Interviews were transcribed and coded in line with themes identified during preliminary research: looking at the agency of developers, the (potential) role of the state, and corporate strategies.

In addition to documentary and discourse analysis, and interviews, some ethnographic work was carried out. Over the course of four years, I attended informal meetings and social events with those involved in London's real estate. These meetings, often part of the industry's post-work drinks or networking events, were sites where real estate professionals exchanged perceptions on projects, likely market developments, and future ideas. During these experiences I primarily conducted participant observation, but on a few occasions real estate professionals were interviewed. Whilst these actors were not directly involved in the development of Silvertown and are therefore not included in this paper, they worked at prominent real estate consultancies and were vital in informing my understanding of the development process.

\section{Introducing Silvertown: the site, team and their project}

London's Royal Docks are in the east of London (Map 1). The land is owned by a subsidiary of the mayor, Greater London Authority's Land and Property Itd. (GLAP) and is subdivided with Silvertown Quays located in the south-west of the docks (Map 2). The local planning authority is the London Borough of Newham, who were (at the time of fieldwork) considered very pro-development (Duman et al., 2018). Aside from GLAP and Newnham's roles in the area, the public sector also oversees development through the site's Enterprise Zone status, the docks' role within east London's 'Arc of Opportunity', the guidance of the mayoral strategic planning authority and because the docks are one of the mayor's identified 'Opportunity Areas'. This complicated public sector involvement is often used by the private sector to explain why the site has not been redeveloped (Brownill and Carpenter, 2007). However, in 2012, following extensive consultation between potential developers and the London Development Agency, the GLA selected 'preferred partners' for some of the larger sites, including Silvertown Quays. Following this, the GLA signed a Master Development Agreement with 'The Silvertown Partnership' (TSP) in 2013. 


\section{[insert Map 1, Map 2]}

Newham, the Mayor, the LDA and local personalities all united around the idea of regenerating the docks, and any differences between potential developers, the business-led LDA and Newham were overcome through the work of Clive Dutton, a regeneration expert who "was able to bring parties together, inspire and cajole, find the money and, often as not, put on a great show" (Bishop, 2015). Dutton had worked across the UK on regeneration projects (for example head of regeneration at Birmingham City Council) and was hired by Newham in 2009 to focus on 'inward investment' in the lead up to the London 2012 Olympic Games. In the docks, Dutton created a 'Developers Forum' to bring together those working in the area and create commercial confidence.

Arguably, this phase exhibited many of the core characteristics of an urban regime (Dowding et al., 1999). A policy agenda centered on regeneration was sustained through a 'grand coalition', in this case across the LDA, Newham, the London Mayor and local interests, in a way which crosses sectoral and institution boundaries. Its longevity and capacity to mobilise extensive public and private sector resources was facilitated by strong or exceptional leadership, by developers and entrepreneurial leaders in local government. However, in the Docks, in recent years, the politics around the regeneration agenda has received heightened attention. In particular, local artists and journalists have highlighted the deliberate courting of developers by both Newham and the London Mayor (Duman et al., 2018). There is, as this work attests to, a pressing need to understand how narratives around regeneration are applied as a marketing tool, and the consequences of this in terms of what gets built. Much of this activism focuses on the Royal Albert Docks, Silvertown's neighbour, and the idea of a 'supernova' of Chinese development which was employed metaphorically by the public sector to inspire investors. At the same time, in Silvertown, James (2018) points out, marketing explicitly says "Silvertown is not for everyone", it's therefore important to understand how the processes which follow on from the local authorities' marketing enabled developers to dominate the governance of subsequent development.

Turning to the selected developers, TSP is a three-way consortium consisting of: Chelsfield, a global real estate company with offices in London, Paris, New York and Hong Kong (formerly run by Stuart Lipton); First Base, a London focused primarily residential developer 
headed by Stuart's son, Elliot Lipton; and Macquarie Capital, a global investment and financial services corporation. The partnership collectively set the project's brief, with each company financially investing, and both Macquarie and First Base having specific tasks set out in development agreements between them and the partnership. First Base led the delivery of the project and as such had to secure the necessary documentation for the planning permission application. Outside the project, they act as the public face and are the primary people the public sector deals with. Within the project, they function as the co-ordinator of wider development processes, drawing together the necessary teams and mediating between the masterplanning exercise and formal governance institutions. Whilst a young company, relative to the wider London scene, they have experience in two of London's most recent developments: the Olympic Village and Kings Cross. TSP are therefore significantly more complicated than the lean organisation Coiacetto (2001) identified in Australia and instead speaks to the idea that development organisations, in response to the need to understand 'product location and timing' (Adams et al. 2012), create a team with differing expertise in order to obtain the necessary skills.

In 2012 TSP put forward a vision for a 'brand destination' for 3,000 new homes and 20,000 new jobs. The idea was considered by others involved from the private sector to be "Very, very clever and forward thinking" (IC 2404/17). This praise extended to the public sector and TSP's plan was strongly supported by the local state, as one public official explained: TSP "won the development bid on the basis that their proposition was bringing employment rather than purely residential" (Consultant 1 02/03/177). However, concerns around what the socio-material realities of a brand destination would be began to surface quickly, as one consultant explained:

"I think it became clear after the bid was won that it [the brand destination] wouldn't stack up on that basis. There weren't sufficient numbers of people who would sign a cheque for their individual building" (Consultant 1 02/03/177).

In response to the growing critiques, and concerns about the financial viability of the project, TSP put forward a moderated version of their plan. Their revised version was announced in 2014, a year after winning the bid: "Our vision for Silvertown Quays will create a new piece of our city with entrepreneurship, innovation and knowledge economies at its heart". Importantly, despite some evolution of their vision, TSP remained contractually obliged to meet the objectives of their agreement with GLAP. Addressing this, TSP argued the agreement 
would be upheld through the design of three main building typologies within the broad category of 'Brand Buildings' (a phrasing they introduced, demonstrating their capacity to 'carve out' a space within the institutional setting). This enabled them to balance investor expectations and still be part of the "changing face in how brands engage - not about straight forward transactions" (RF 12/06/17). To market the site, they grounded it in existing understandings of London's urban development, drawing on particular imaginations within London. Specifically, in media releases they identified and consolidated the view of themselves as 'the new Shoreditch': a centre for creativity elsewhere in London (Cahill, 2016).

To implement their vision, TSP hired an extensive team of consultants. On the technical side they hired Fletcher Priest, London architects, to lead the urban design and planning application process. Fletcher Priest worked directly with TSP's selected town planning consultants, Quod, another London based firm, who have a particular expertise in working with Newham. In addition to these core functions, the masterplan was informed by engineers from Arup, architectures from West8 in the Netherlands and London's AKT II, and heritage specialists Donald Insall. The masterplanning process was characterised by "debates conducted with project's team, with a good degree of professional conduct and civility. There's a sort of established way of thrashing out differences" (Consultant 6, March 2017). These differences were based on professional understandings, as well as individuals' underlying motivations. Interviewees explained how for some in the project, it was about making Silvertown into a place "where people want to be" (Developer 2, March 2017) or which would "make their grandchildren proud" (Consultant 3, June 2017). As one developer described their resultant position: "It doesn't matter what the professional background of that person is - it's [about] sitting above the individual disciplines and getting them to talk together and keep them moving" (Developer 4, June 2017). Outside the planning application process, CBRE were hired to help direct the procurement of external funding for the project. Therefore, throughout the early stages of development, TSP coordinated a body of experts, worked with multiple public sector bodies and engaged the local community.

\section{Responding to their wider network: creating multiple sub-centres of power}

In this section I address how the team outlined above, and the perceived political, community and financial risk (Geva and Rosen, 2018; Brill and Robin, 2018), shaped TSP's strategy. I argue that in response to their vast team, TSP managed their experts and associated interactions with communities and the public sector through three sub-centres of power. This 
strongly contrasts with the idea of the developer as the sole co-ordinator and of an industry dominated by "atomised behaviour that anyone with the right frame of mind can be successful" (Adams et al., 2012: 2582).

\section{Sub-centre 1: The technical lead}

The first sub-centre was the team lead for the technical dimensions of the masterplanning process. Acting on behalf of TSP and First Base, the lead at Fletcher Priest made the vast majority of the day to day decisions. He described his work as drawing together the "technical material supporting that [the masterplan]" which was "supported by design studies at a building scale, but abstracted into higher level special parameters that are in the environmental assessment" (Consultant 1, March 2017). This illustrates the technical complexity of the process. As he explained it:

"So part of the role of being lead consultant is to be able to lead and co-ordinate the design team [..] I think, one of the key things is that you get lots of people working who by definition have to go off and do their various things, and it's about asking at what point do you have to control or bring them together" (Consultant 1, March 2017).

Understanding the decision to hire a design-based technical lead in many ways helps inform the research agenda sketched out by Adams and Tiesdell who argue that one "research priority would be a thorough study of why attitudes to the value, benefits and costs of design vary between developers. This type of research needs to set design issues alongside other demands on corporate strategy" (2014: 298). The sub-centre lead's technical knowledge, which TSP does not have in-house, allowed him to make judgements about how to bring together different understandings of the development trajectory. This technical role required navigating the socialised, and in many ways institutionalised through professional qualifications, approach to development (Harvey, 1989). As Tiesdell and Allmendinger, drawing on Harvey (1989) explain "property developers [..] firms and other organisations develop 'house views' relating to how they see the world" (2005: 70). Applying this to Silvertown, each of the consultants' specialisms and associated professional development result in them perceiving the plan in different ways, which requires leadership by the developer - or in this case the technical lead. 
On the face of it, allowing the consultant to lead meant reducing TSP's control over the process. However, to some extent, this impact was limited because TSP (by proxy First Base) remained relatively "hands on" (Developer 1, May 2017), taking the time to oversee any developments to the plan during weekly meetings formed. However, at a very detailed, technical level, decisions were led by Fletcher Priest. As the lead from First Base explained:

"When we started with the re-looking at the masterplan I was probably sitting down with [Fletcher Priest] as our master-planner twice a week [..] we brought on other consultants to manage the environmental impact assessment, the other advice we needed" (Developer 1, May 2017).

\section{Sub-centre 2: The Development Manager}

First Base used in-house management expertise to navigate the relationship with Fletcher Priest. This relationship dictated the agency of the consultant lead since Fletcher Priest's control of the situation "depends on the degree to which there's a specific project manager as a discipline [..] or whether the client has project management in house" (Consultant 1, March 2017), which First Base did. This leads to the second sub-centre of power, the development manager at First Base, who mediated between technical knowledge and the public sector, and aligned technical knowledge (the Masterplan, Design and Access Statement and the Design Codes) with investor expectations.

This role was seen by most interviewed to be a general management position and in Silvertown, "in terms of development or project management services that's one of the things First Base brings" (Consultant 1, March 2017) - there was an understanding "within the general organisation of how the information feeds in to any different stage of the process" (Developer 1, May 2017). This included bringing together TSP's vision to sell to investors, a process which was largely described as 'story telling' (ibid.). This required the development manager to forge relationships across consultancies, to understand how different forms of expertise fed into the design process, and then relate this to potential financiers. As on interviewee explained:

As a development manager you have to "If you say to most investors, who might be based in China or Singapore or Kuala Lumpur, 'we're going to do a project in West- 
minster in London', they go 'ok we understand where that is' - the Houses of Parliament etc. If you say 'we're going to do a project in Newham' - they go 'where is it, in Manchester?' So you do have to spend a lot more time. And you have to do more in terms of demonstrating why it's a good thing to invest in." (Developer 1, May 2017).

As is evident in the quote, the first part of the management role is very much centred on mitigating financial risk, loss of investor confidence and defining the market(ability) of the project. Positioning the project as an asset for investors, First Base's Director worked with CBRE to connect with potential investors. This process was complicated by the structure of TSP. The three way division of powers (and responsibilities) meant Macquarie Capital were largely responsible for bringing in the majority of funding. As one interviewee explained: "For them, that was just an investment. And to assist in terms of procurement of the funder. In the same way we have a development management role they have a fund advisory role" (Developer 1 26/05/17). This should have meant First Base took a backseat, but the nature of the individuals involved in the project meant First Base remained involved. This reveals how the process of integrating financial expectations into overarching development patterns is contingent on the corporate structure. In this case, the decision by First Base to remain heavily involved directly shaped the extent to which financial logics will have been integrated into the design process, since it was mediated through the development manager, who directly represented and propagated TSP's vision.

The second part of this management role is about developing and maintaining public sector and community relations. In much the way financialisation literature identifies the way developers are positioned between the state and investors (Weber, 2015), in Silvertown this position was occupied by the development manager. In this case, First Base led meetings with the planning authority, Newham. This relationship was described as relatively easy to manage because planning was seen as "rational" and "not restrictive" (Developer 1, May 2017). TSP still had to interact extensively with the public sector though, especially debating affordable housing, because the UK planning system has explicitly embedded developers' viability in planning gain discussions with the state (Christophers, 2014).

In Silvertown interaction with the state was further complicated because the land is publicly owned, where TSP interacted constantly with GLAP. As was explained: "they own the land, [TSP] have a development agreement with the GLA which sets the rules and objectives of what we're trying to achieve and we have to report to them [..] in the same way that we 
report to the Silvertown Partnership" (Developer 1, May 2017). Despite this, TSP still saw the role of GLAP positively: “You've got a joint venture partner in the GLA which is absolutely wedded to regeneration in the docks and you've got a very willing local authority who wants to see jobs for its residents. And you know, that's a great starting point". GLAP was therefore not necessarily a constraint on development, as the planning media noted "by and large, they have also shown the GLA acting as catalyst to development, as opposed to a bureaucratic hurdle" (Northey, 2015). But being pro-development did not mean TSP were exempt from planning requirements: "You can do a joint venture with a local authority, but at sort of top level it doesn't buy you any favours through the planning processes, you've still got to meet the rules" (Developer 1, May 2017). Understanding how such 'rules' were to be interpreted, especially in line with GLAP priorities, was the responsibility of the development manager.

\section{Sub-centre 3: The Project Figurehead}

The final sub-centre of power was Stuart Lipton who functioned as a figurehead for the development and in doing so garnered wide-ranging support, media interest and respect from those within the real estate community. His role helped to mitigate risk from wider objection (Geva and Rosen, 2018), as well as more broadly assisted in minimising political and financial risk through his networked reputation (Henneberry and Parris, 2013). Additionally, Lipton can be understood to have helped translate the periphery of London to a less risky location for investment (David, 2012).

Lipton's role was explained by a lead consultant: "What's interesting is to understand the role of somebody who might be driving it as a figurehead [..] Which is his incredibly important role" (Consultant 11, March 2017). After leaving Chelsfield, Stuart functioned as the face of the scheme which was widely scrutinised because of its size and relative strategic importance within a brownfield-prioritising planning system and neighbouring City Airport development. Lipton's role as a figurehead in this respect was important because it enabled TSP to leverage media support for Lipton and to promote their peripherally located development in mainstream media. This in turn increased the prominence of Silvertown, helping establish it on the map of potential investment in London (Developer 1, May 2017), and whilst the bulk of investment decisions are likely a reflection of the details of plans, having Lipton involved in the project brought credence to its (financial) potential. 


\section{The consequences of sub-centres of power for urban governance}

The web of consultants and consequential pluralistic centers of co-ordination influenced the governance of the site by making the system more opaque. Specifically, the multiple levels of co-ordination within the realms of the private sector had two consequences: (1) they internalised decisions to the private sector; and (2) they confused people external to the organisation. These directly shaped TSP's capacity to navigate urban governance settings because it enabled them to limit the number of options put to wider debate and divorce themselves from the consultation process, thereby reducing scrutiny of their project.

\section{Consequence 1: internalisation of decision-making}

The first consequence of such extensive co-ordination is the internalisation of decision- making to the private sector. Throughout the development process, especially in the early stages, consultant team meetings provided opportunities for different experts and even the public sector to shape the developmental outcomes. During these meetings the development manager co-ordinates the process and within this they dictate the agenda, where ideas advanced by consultants which are deemed 'less appropriate' are never made public. One particular example, repeatedly addressed during interviews, was water management. In various interviews developers and engineers returned to the issue of how to manage the water in the docks and leverage its potential to benefit the site. This began when one manager explained that First Base are "innovative" and wanted to "push the boundaries" of normal practices (Developer 1, May 2017), in particular through a novel approach to water management. As he and the engineer involved explained, this would reduce the environmental impact of the water (Engineer 1, April, 2017). However, the planning system had little guidance on how to deal with this and so whilst the developer and some consultants had explored its potential, the idea was never made part of the public discourse because it may have significantly delayed planning applications.

The impact of the internalisation was exacerbated by the nature of who is included in consultant meetings. Whilst there is an element of diversity in design professionals, it is worth noting, as was highlighted during a moment of critical self-reflection by one consultant, that the views of consultants remain relatively narrow: 
"I'm always conscious in design team meetings [that] we're all speaking from broadly educated, design interested, backgrounds. And so while we do represent many views, we can't represent all views." (Consultant 8 , March 2017).

This statement implicitly acknowledges that the realms of design expert debates are perhaps ignorant - or at least less mindful - of the views of communities and non-experts. Instead, the focus is on integrating perspectives which the consultant quoted above considered relatively similar. In many ways this was echoed by another of the niche consultants who noted that in design meetings "you're already working with people that are selected for being on the same wave length, as are all the people working for the partnership" (Architect 1 February 2017). This shared understanding is perceived to be vital for developers though: it allows them to meet development goals on time. As such, TSP specifically debated options within their organisation, rather than opening it to external debate.

Echoing existing analysis on risk (see Geva and Rosen, 2018), one interviewee explained: "for developers like First Base, the thing that hurts your return the most is time. It takes you longer to do stuff, the cost of money holds you down. There's always this balance between challenging the norm and actually delivering on time" (Developer 4, April 2017; Brill and Robin, 2018). This reveals the role of time in linking financial threats to urban governance. Any time 'wasted' is understood as money lost, therefore decisions are rushed which could have significantly negative consequences. In response to time pressure developers internalise decisions. Addressing this in interviews, most discussions centered on the cumbersome nature of planning authorities which mimicked narratives around planners as 'time wasters' (Clifford, 2016), and instead there was a desire to have structures that enable developers "to act freely to get on with the process of making development happen" (Raco, 2013: 177).

Moreover, because of the involvement of the GLAP as strategic partners and the pro-development stance of Newham (Duman et al., 2018), delivering jobs and housing in a timely manner was perceived to be of upmost importance. Indeed, across the UK public authorities are increasingly under pressure to get planning applications through on time. As Clifford (2016) notes, the shift from development control to development management by UK planning authorities has been accompanied by the instigation of time related targets. These put pressure on the planning authorities to address applications within a specific time, with the 
threat of national government intervention if they consistently fail to meet them (HM Treasury, 2015). This time-related incentive is therefore shared by different actors within the development process and not only encourages a more opaque decision-making process, but also perverts the extent to which policy evolution occurs. Moreover, the longevity of the attempts to regenerate the docks underpinned this sense of urgency, evident in both policy discourses and interviews.

\section{Consequence 2: A more opaque public consultation}

The second consequence of multiple layers of co-ordination develops from the internalisation of decision-making. With more consultants involved in the site, it becomes increasingly challenging to understand the division of responsibilities. This is especially true for those outside of the development organisation, and in Silvertown it directly limited the community's capacity to engage. A big challenge for those who live in the area and are involved in the site or who want to shape the development trajectory, who are not part of the official development organisation, is understanding who has control or jurisdiction. During one field visit, a local historian explained: as far as he was concerned, people in the area struggled to understand who was in charge of the development and therefore who to ask questions to. This confusion was compounded by the division of landownership and development rights, where even those on the site struggled to fully recollect the division of rights:

"They own $70 \%$ of the land, not an exact figure, but there's a portion of the site that is still owned by Newham. But basically the ownership is in the public realm. There are some complex ownerships" (Engineer 5, March 2017).

As is evident in this quote, despite having extensively surveyed the land as part of his work, the engineer was unable to fully articulate the different land rights. Interviews with local community leaders suggested that the complex division of land ownership inhibited those who wished to engage with the development process.

The initial problems of understanding who has the rights to develop particular areas were compounded by TSP's approach to participation. Public participation is a mandatory part of planning processes in the UK and whilst existing research has noted the main pitfalls of such an approach (Healey, 1998; Coaffee and Healey, 2003), it remains a key tool in a local communities' capacity to shape what might happen to an area. 
In the case of Silvertown, TSP hired London Communications Agency (LCA) to lead this process. LCA are a public relations firm who specialise in the built environment and work across London. Luckily for LCA and TSP "the Liptons have certainly been seen as people doing a lot of good for the area that can bring or can help deliver the regeneration of the Docks as a whole and Silvertown in particular" (Consultant 10, March 2015). However, "Stuart doesn't walk in to a room of consultation events around a table like this with you know 15 local stakeholders and you know the headmistress of the school" (Consultant 10, March 2015). Rather LCA were hired to do this work and establish the necessary relationships with the local community, including addressing any risk they might pose to the development. TSP explained their involvement as part of "a comprehensive pre-application consultation process [..] first with key identified stakeholders and then a two stage process with the wider public" (Fletcher Priest, 2014).

The first part of consultation with the public was two exhibitions where TSP displayed their vision for the site and the community was invited to respond. In their subsequent Design and Access statement, TSP highlighted the community's primary concerns. The first major theme was around what would happen to a historical building, the Millennium Mills, including its restoration. This is a key part of the scheme as envisioned by TSP, therefore these concerns were pacified by referencing the centrality of the rebuilding. The second theme was integrating existing neighbourhoods, especially Britannia Urban Village which directly neighbours the site, which TSP noted would be acknowledged in their Design Codes (2014). Finally, concerns around transport integration were raised and TSP responded by noting they were in continual dialogue with Newham and Transport for London about how best to proceed. These responses can be seen to reflect the flexibility Robin (2018) notes in her analysis of the King's Cross team's responses to community concerns. Additionally, the depth of their engagement can be understood to reflect the 'tokenistic' nature of many participatory approaches (Arnstein, 1969) where the wishes of those consulted are never fully considered (Peterman, 2000) and instead perceived value-free responses by developers enable them to marginalise any radical alternatives (Allemdinger and Haughton, 2012).

In terms of understanding the impact of the sub-centres of power, it is necessary to look at how LCA shaped the consultation process. In parallel to the exhibition were a number of LCA initiatives, some of which are standard community consultation processes such as leaf- 
letting, whilst others were more innovative. For LCA, the approach adopted to mitigate community risks has to be tailored to the site, as was explained during one interview, even for more traditional approaches "You're always going to have to find an agreeable catchment area in which you're going to leaflet drop and write to everyone" (Consultant 10, May 2015). These approaches were considered necessary for part of the "robust" planning procedures, but as is indicative in the following quote, LCA perceived them to be less interesting, preferring to engage in different ways: "the fact that we have very active schools in the local community is very helpful but we still write to everybody, publish in the local papers - all those sorts of, kind of, requirements" (Consultant 10, May 2015). This level of activity was also reflected upon during interviews with local school and community leaders. In this respect LCA can be seen to have defined who was the 'community', facilitated at least in part by the institutional setting where the developer is responsible for community engagement rather than the local authority, and by engaging with participatory approaches, are capable of defining whose voice was a legitimate representation of community. Their resultant conceptualisation of community speaks to what Healey (1998) has highlighted are the limitations of community-led development, where the concept of community is used to refer to those who are in opposition to developers or business.

When developing a more site-specific approach, LCA focused on local schools: "schools are very helpful because young people are the most excited about what's going on there they're the people that live there and that Newham would hope would one day would work and stay there rather than getting to whatever age and leaving". For them, working with children was important because "getting them on side - telling them about the history it's very easy to get them engaged and from that to then go home" and tell their parents about the schemes (Consultant 10, May 2015). LCA also "got artists on site - a more touchy-feely PR way but also very important in the project as a whole" (Consultant 10, May 2015) in terms of the focus on creativity more generally. Such funding of artistic projects was something members of the community were drawn to, during an interview with one local they highlighted that LCA and TSP were prepared to sponsor a range of events - even a dance show. This created a general sense of positivity towards these organisations.

In this respect, LCA can be understood to have formed a core element of what Geva and Rosen (2018) and Brill and Robin (2018) have categorised as developers' political or community risk mitigation. It was through LCA that the community were meant to channel concerns to TSP. Yet in Silvertown, LCA and TSP became synonymous, one local community 
member explained "you just have to talk to [LCA]". This directly builds on earlier analysis of how structural changes to the British planning system have enabled the proliferation of planning consultants and experts who then function in 'anti-political machines' (Raco et al., 2016). For Raco et al pluralism in planning or "is being mediated through these machinelike arrangements" which leave little room for citizen engagement (2016: 236). Whilst the example of the LCA undoubtedly supports this to some extent, it also demonstrates how for some period of time the community did have a clear point of contact. However, this contact was from a public relations firm, rather than the developer.

Additionally, The impact of LCA was compounded because they had little access to the actual masterplanning process, and by the time the planning application was submitted they were no longer working for TSP. This distance from the developer and change of circumstance both exacerbated the communities' difficulties in trying to understand who they could contact when the application went to be discussed by the planning authority. The ways in which TSP dealt with the community therefore adds further complexity to the impact of subcentres of power because it shows how it creates opacity and also reveals how the structure of the relationships within the private sector, the frequency and quality of communication, and the length of consultants' involvement shapes the way devolving control over participation to a consultant impacts development outcomes.

\section{Conclusion}

This paper makes three key contributions to the on-going theorisation of the private sector in urban governance. Firstly, building on the existing literature on real estate developers, by beginning analysis from their perspective, it informs a critical engagement with their strategy. If the aim of a developer is to build their project and maximise profits, then, supporting research on the relational work of developers, the case of Silvertown shows that developers' work is about forming strategic alliances that enable this. These relationships not only facilitate the gathering of knowledge and feed into an increasingly professionalised development scene (Hofman and Aalbers, 2019), but also enable developers to dominate governance situations. In this paper, advancing these arguments I show the next stage of the corporate response: the creation of sub-centres of power which facilitate the developers' capacity to orchestrate development processes. 
Secondly, in critically engaging with the resultant network and sub-centres of power, this paper advances understandings of how such corporate strategies directly and indirectly feed into wider interactions between the public and private sector. Specifically, I argue developers are able to reduce external critique of potential ideas voiced by consultants during the planning process. Additionally, by hiring PR firms and devolving control of participatory processes, developers are able to obscure who is perceived to be in control of development, thus sheltering themselves from extensive debate. This is important to understand in the context of expert-led forms of urban development (Robin, 2018) because it can help inform public sector and community engagement strategies.

Finally, both of these outcomes ensure the developer maintains a central position in debates, but they are also demonstrably driven by time-pressures. By focusing on how time shaped the developer's strategies, I revealed the practice through which the private and public sectors align. This of particular importance because of the way interests in the docks assembled around the idea of 'regeneration' and the perceived 'problems' of the area. Across those interviewed, the idea that the docks regeneration was urgent underpinned the drive for a 'coalition' centred on general economic improvement (see Stone, 1989), rather than specific business interests.

This paper focused on the period of planning application, but as projects develop different relationships become increasingly important. It is therefore necessary for future research to continue this agenda, addressing the work of the developer using an insider perspective in an effort to understand how their strategies - be they deliberate or the by-product of others' actions - influence their agency and position in governance. Moreover, in demonstrating how the developer employs such extensive consultant teams and their relative power once hired, in terms of the developer being reliant on them for their specific task, sheds light on the forces internal to the private sector which challenge developer agency. This suggests the need for research that unpacks how contrasting understandings within the private sector have demonstrative material impacts. 


\section{References}

Aalbers M (2017) The Variegated Financialization of Housing. International Journal of Urban and Regional Research, 41(4)

Aalbers M (2015) The Great Moderation, the Great Excess and the global housing crisis, International Journal of Housing Policy, 15:1, 43-60

Adams D, Croudace R and Tiesdell S. (2012). Exploring the 'Notional Property Developer' as a Policy Construct. Urban Studies, 49(12), 2577-2596

Allmendinger P and Haughton G (2012) 'Post-political spatial planning in England: A crisis of consensus?', Transactions of the Institute of British Geographers, vol. 37, no. 1, pp. 89103

Akers J (2015) Emerging market city. Environment and Planning A, 47(9), 1842-1858

Arnstein S (1969) 'A Ladder Of Citizen Participation', Journal of the American Planning. Association, 35: 4, $216-224$

Attuyer K, Ludovic H and Antoine G (2012) "Turning pumpkins into carriages": sustainable urban development and the financialization of 'green' commercial real estate in France. Articulo: Journal of Urban Research

Bishop P (2015). Clive Dutton obituary. The Guardian. Retrieved November 8, 2018, from https://www.theguardian.com/society/2015/jun/29/clive-dutton

Brill F (2018) Playing the Game: an international comparison of real estate developers in Modderfontein Johannesburg and London's Royal Docks, Geoforum (2018), https://doi.org/10.1016/j.geoforum.2018.05.015

Brill F and Robin E (2018) The Risky Business of Real Estate. The Bartlett School of Planning Seminar Series, London, October 23rd 2018

Brownill S and Carpenter J (2009). Governance and 'Integrated' Planning: The Case of Sustainable Communities in the Thames Gateway, England. Urban Studies vol. 46(2), pages 251-274

Cahill H (2016). Silvertown development in London's Royal Docks gets planning permission. CityAM.

Campbell H Tait M and Watkins C (2013). Is There Space for Better Planning in a Neoliberal World? Implications for Planning Practice and Theory. Journal of Planning Education and Research, 34(1), 45-59

Charney I (2007) The politics of design: architecture, tall buildings and the skyline of central London. Area, 39(2), 195-205 
Christophers B (2014) Performative world- making of economic models, UK case. International Journal of Urban Regional Research, 38: 79-97.

Coiacetto $E$ (2001) Diversity in real estate developer behaviour: A case for research. Urban Policy and Research, 19(1), 43-59.

Coiacetto E (2007) The Role of the Development Industry in Shaping Urban Social Space: a Conceptual Model. Geographical Research, 45: 340-347

Clifford B (2016) 'Clock-watching and box-ticking': British local authority planners, professionalism and performance targets. Planning Practice \& Research, 31(4), 383-401

Coaffee J and Healey P (2003) 'My Voice: My Place': Tracking Transformations in Urban Governance. Urban Studies, 40(10), 1979-1999

Corpataux J, Crevoisier O, Theurillat T. (2009) The expansion of the finance industry and its impact on the economy: A territorial approach based on Swiss pension funds. Economic Geography 85(3): 313-334.

Cox K (2017) Revisiting the 'City as growth machine' Cambridge Journal of Regions, Economy and Society 10:3 (2017), 391-405

Crosby $\mathrm{N}$ and Henneberry $\mathrm{J}$ (2016). Financialisation, the valuation of investment property and the urban built environment in the UK. Urban Studies, 53(7), 1424-1441.

David L and Halbert L (2014). Finance Capital, Actor-Network Theory and the Struggle Over Calculative Agencies in the Business Property Markets of Mexico City Metropolitan Region. Regional Studies, 48(3), 516-529

David $L$ (2012) The social construction of real estate market risk. The case of a financial investments cluster in Mexico City. Articulo - Journal of Urban Research [Online], 9 | 2012, DOI : 10.4000/articulo.2163

De Magalhães CS. (2001) International property consultants and the transformation of local markets. Journal of Property Research 18(2): 99-121.

Domaradzka A (2019) The un-equal playground: Developers and urban activists struggling for the right to the city, Geoforum doi.org/10.1016/j.geoforum.2019.01.013.

Dowding K (2001) Explaining urban regimes. International Journal of Urban and Regional Research 25 (1) 7-19.

Dowding K, Dunleavey P, King D, Margetts H and Rydin Y (1999) Regime politics in London local government. Urban Affairs Review 34 (4) 515-545.

Duman A, Hancox D, James M and Minton M (2018) Songs of Regeneration: Sound of Investment and Loss from East London London : Penguin Books

Elkin S (1987). City and Regime in the American Republic. Chicago, IL University of Chicago Press. 
Fainstein S (2001) The city builders : property development in New York and London, 19802000 (2nd ed.). Lawrence: Lawrence : University Press of Kansas.

Fernandez R, Hofman A and Aalbers M (2016). London and New York as a safe deposit box for the transnational wealth elite. Environment and Planning A, 48(12), 2443-2461

Fields D (2017) Unwilling Subjects of Financialization. International Journal of Urban and Regional Research, 41(4), 588-603

Geva $Y$ and Rosen $G$ (2018) The regeneration deal: Developers, homeowners and new competencies in the development process. Geoforum, 96, 10-20.

Gotham K (2009) Creating Liquidity Out of Spatial Fixity: The Secondary Circuit of Capital and the Subprime Mortgage Crisis. International Journal of Urban and Regional Research 33 (2): 355-71

Guironnet A, Attuyer K, and Halbert L. (2016). Building cities on financial assets: The financialisation of property markets and its implications for city governments in the Paris cityregion. Urban Studies, 53(7), 1442-1464

Halbert $L$ and Attuyer K (2016). Introduction: The financialisation of urban production: Conditions, mediations and transformations. Urban Studies, 53(7), 1347-1361

Halbert L, and Sanfelici D (2016). Financial markets, developers and the geographies of housing in Brazil: A supply-side account. Urban Studies, 53(7), 1465-1485.

Halbert L and Rouanet H (2014) Filtering Risk Away: Global Finance Capital, Transcalar Territorial Networks and the (Un)Making of City-Regions: An Analysis of Business Property Development in Bangalore, India. Regional Studies, 48(3), 471-484. doi:10.1080/00343404.2013.779658

Harvey D (1989). The condition of postmodernity: An enquiry into the origins of cultural change. Oxford

Healey P (1998). Collaborative Planning in a Stakeholder Society. The Town Planning Review, 69(1), 1-21.

Heeg S, and Bitterer N (2015), "Communities of Practice and Transnational Standards: Changing Building Practices in Warsaw's Commercial Property Sector", Global Networks, 15 (3).

HM Treasury (2015) Fixing the foundations: Creating a more prosperous nation (London: HM Treasury)

Henneberry J and Parris S (2013) The embedded developer: Using project ecologies to analyse local property development networks. Town Planning Review, 84(2), 227-249 Hofman A. Aalbers M. (2019) A finance- and real estate-driven regime in the United Kingdom, Geoforum, Volume 100, Pages 89-100 
Holman N (2007) Following the signs: applying urban regime analysis to a UK case study. Journal of urban affairs, 29 (5). pp. 435-453.

Hyde Z (2018). "Giving Back to Get Ahead: Philanthropy as a Developer Strategy of Accumulation in Public-Private Social Housing," Geoforum

Imrie R (2009.)'An exemplar for a sustainable world city': progressive urban change and the redevelopment of King's Cross. In: Rob Imrie; Loretta Lees and Mike Raco, eds. Regenerating London: Governance, sustainability and community in a global city. Abingdon: Routledge, pp. 93-111

Leffers D (2017) Real estate developers' influence of land use legislation in the Toronto region: an institutionalist investigation of developers, land conflict and property law. Urban Studies.

Logan J. R. and Molotch, H.L. 1987. Urban Fortunes. Berkeley and Los Angeles: University of California Press.

Mayor of London (2014) Artists' Workspace Study Report, Greater London Authority UK, September

Moore S, Raco M, and Clifford B (2018). The 2012 Olympic Learning Legacy Agenda - the intentionalities of mobility for a new London model. Urban Geography, 39(2), 214-235.

Mossberger K. (2009). Urban regime analysis. In Theories of Urban Politics, Second Edition (pp. 40-54). SAGE Publications Inc.Mossberger, K., \& Stoker, G. (2001). The Evolution of Urban Regime Theory: The Challenge of Conceptualization. Urban Affairs Review, 36(6), 810-835.

Northey J (2015). A very public (and private) affair. The Estates Gazette, 50.

Peterman W. (2000) Neighbourhood Planning and Community based Development: Potentials and Limits of Grassroots Actions, Sage publications, London

Raco M (2014) Delivering Flagship Projects in an Era of Regulatory Capitalism: State- led Privatization and the London Olympics 2012. International Journal of Urban and Regional Research, 38(1), 176-197.

Raco M, Street E and Freire-Trigo S (2016). The New Localism, Anti-Political Development Machines, and the Role of Planning Consultants: Lessons from London's South Bank. Territory, Politics, Governance, 4 (2) pp. 216-240

Robin E (2018) Performing real estate value(s): real estate developers, systems of expertise and the production of space Geoforum https://doi.org/10.1016/j.geoforum.2018.05.006 Rolnik R (2013), Debates and Developments. International Journal Urban Reg Res, 37: 1058-1066. 
Rosen G (2017). Toronto's condo- builders: development approaches and spatial preferences. Urban Geography, 38(4), 606-625. doi:10.1080/02723638.2016.1179426

Rouanet $\mathrm{H}$ and Halbert $\mathrm{L}$ (2016). Leveraging finance capital: Urban change and self-empowerment of real estate developers in India. Urban Studies, 53(7), 1401-1423.

Roy A (2009) "Why India Cannot Plan Its Cities: Informality, Insurgence and the Idiom of Urbanization." Planning Theory 8, no. 1: 76-87.

Sagoe C (2018) Technologies of Mobilising Consensus: The Politics of Producing Affordable Housing Plans for the London Legacy Development Corporation's Planning Boundary. Planning Theory \& Practice, 19(3), 327-344.

Searle L (2014). Conflict and Commensuration: Contested Market Making in India's Private Real Estate Development Sector. International Journal of Urban and Regional Research, 38(1), 60-78

Shatkin G. (2014) Contesting visions of the Indian city. Int J Urban Reg Res, 38: 1-13

Shatkin G. (2011) Planning Privatopolis: Representation and Contestation in the Development of Urban Integrated Mega- Projects. In Worlding Cities (eds A. Roy and A. Ong).

Shatkin G. (2008) The City and the Bottom Line: Urban Megaprojects and the Privatization of Planning in Southeast Asia. Environment and Planning A: Economy and Space, 40(2), 383-401.

Stone C (1989) Regime politics: Governing Atlanta, 1946-1988. Lawrence: Univ. Press of Kansas.

Theurillat T, and Crevoisier, O (2013) Sustainability and the anchoring of capital: Negotiations surrounding two major urban projects in Switzerland. Regional Studies 48(3): 501- 515 Tiesdell S. and Allmendinger P. (2005) "Planning tools and markets: towards an extended conceptualisation". In Planning, Public Policy and Property Markets, Edited by: Adams, D., Watkins, C. and White, M. 56-76. Oxford: Blackwell

van Loon, J. (2016) Patient versus impatient capital: the (non-)financialization of real estate developers in the Low Countries, Socio-Economic Review, Volume 14, Issue 4, 1 October 2016, Pages 709-728

Ward C. and Swyngedouw E. (2018), Neoliberalisation from the Ground Up: Insurgent Capital, Regional Struggle, and the Assetisation of Land. Antipode, 50: 1077-1097

Weber R (2015) From boom to bubble: how finance built the new Chicago: Chicago : The University of Chicago Press.

Weber R (2010). Selling City Futures: The Financialization of Urban Redevelopment Policy. Economic Geography, 86(3), 251-274 
Weinstein L (2014). 'One- Man Handled': Fragmented Power and Political Entrepreneurship in Globalizing Mumbai. International Journal of Urban and Regional Research, 38(1), 14-35 Wijburg G (2019) Reasserting state power by remaking markets? The introduction of real estate investment trusts in France and its implications for state-finance relations in the Greater Paris region, Geoforum doi.org/10.1016/j.geoforum.2019.01.012. 